水文・水資源学会誌

J. Japan Soc. Hydrol. \& Water Resour.

Vol. 9, No.3 (1996) pp. 233-239

\title{
Soil Moisture Observations under Different Vegetations in a Boreal Humid Climate
}

\author{
亜寒帯湿潤気候下における異なる植生条件での土壤水分観測
}

\section{Tomoyoshi HIROTA*}

広田知良

\section{Tatsuaki KASUBUCHI**}

粕㴊辰昭

\author{
(Hokkaido National Agricultural Experiment Station)
}

農林水産省北海道農業試験場

(Faculty of Agriculture, Yamagata University)

山形大学農学部

\begin{abstract}
Soil moisture was observed in situ for three years (1992-1994) to compare the effect of different vegetations (forest, grassland and wheat field) on soil moisture under the same meteorological conditions. The observation sites were located in a boreal humid climate where snow covers for about four months annually. The soil moisture was measured by the heatprobe method (Kasubuchi,1992). It could measure the soil moisture automatically and continuously even under the snow covered condition.

Seasonal variations of the soil moisture was characterized into three stages; from thawing to active vegetation (spring to summer), rainy (autumn) and snow covered (winter) period. The soil moisture and temperature were much influenced by the active time and the root system of each vegetation. Differences in soil moisture among the years depended on the meteorological conditions which affected the vegetation growth.

From these observations, it became clear that the soil moisture and the soil temperature were affected not only by meteorological conditions but also by the vegetations.
\end{abstract}

Key words : Soil moisture, Soil temperature, Heat-probe method, Vegetation, Snow cover

冬季における積雪期間が約 4 ヶ月におよぶ北海道農業試験場(札幌市豊平区, 亜寒带湿潤気候)において, $3 つ$ 異なる植生(森林,

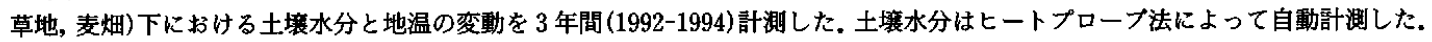
土壤水分の季節変化は消雪後から植生の活動期 (春〜要), 雨期 (秋), 積雪期(冬)の 3 つの時期で特徵づけられた. 各植生下の土堙水 分と地温は, それぞれの植生の活動時期や根圈が互いに異なることによって大きく変化した. 土墴水分の年次間の変動は, 植生の活 動に影墏を与える気象条件に依存していた. これらの結果から, 土裹水分と地温は気象条件のみでなく, 植生条件によって大きく影 讋を受けることを明らかにした。

キーワード : 土壤水分, 地温, ヒートプロープ法, 植生, 積雪

\section{I . INTRODUCTION}

Soil moisture is an important environmental factor for hydrological processes, natural vegetations and agriculture. Recently, it has at- tracted special interest from the viewpoint of climatic variations. However, there were limited number of observational data about seasonal and variations among the years data of soil moisture (e.g., Vinnikov and Yeserkepova,

\footnotetext{
*農林水産省北海道農業試験場 广062 札幌市豊平区羊ヶ丘 1

Hokkaido National Agricultural Experiment Station, 1, Hitsujigaoka, Toyohira-ku, Sapporo 062, JAPAN

**山形大学農学部生物環境学科 7997 山形県鶴岡市若葉町 $1-23$

Faculty of Agriculture, Yamagata University 1-23, Wakaba-machi, Tsuruoka, Yamagata 997, JAPAN
} 
1991; Hollinger and Israd, 1994). This was due to difficulty of measuring soil moisture continuously and nondestructively in the field.

In this report, we adopted the heat-probe method which comprises the measurement of the thermal conductivity of soils with a heat probe and the transformation into soil water contents (Kasubuchi, 1977, 1982, 1992). This method is possible to measure the soil moisture continuously and automatically (Hasegawa and Kasubuchi, 1993).

We measured soil moisture and temperature for three years (1992-1994) to clarify the seasonal variations of soil moisture in a boreal humid climate. In this area, we compared the effect of different vegetations (forest, grassland and wheat field) on soil moisture under the same meteorological conditions. In this observation period, we could also investigate differences in soil moisture among the years, since meteorological conditions in each summer of the three years were quite different.

\section{THE OBSERVATION SITES}

The study site $\left(43.0^{\circ} \mathrm{N}, 141.4^{\circ} \mathrm{E}\right)$ is located in Hokkaido National Agricultural Experiment Station at Sapporo, Hokkaido, Japan. The vegetations of our study sites consist of forest,

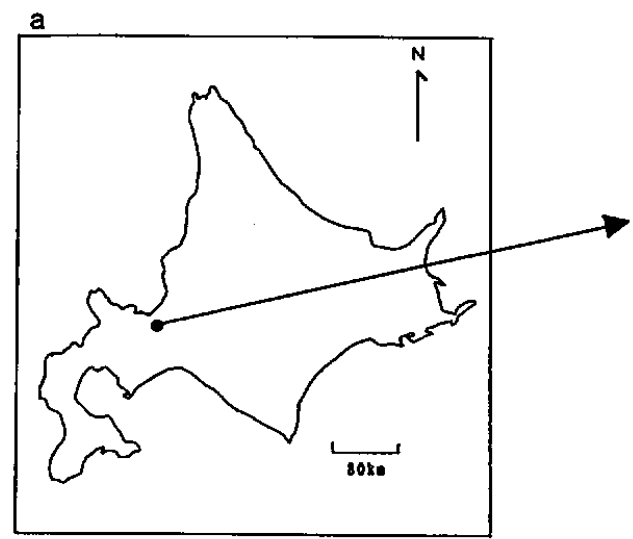

grassland and wheat field, and those were situated in order from south to north within $1.5 \mathrm{~km}$ (Figs. 1 and 2). The vegetation types, the soil textures and the soil properties are shown in Table 1. A meteorological observation station was placed near the east side of the wheat field. The climatic zone of this region belongs to boreal humid. Annual precipitation was about $950 \mathrm{~mm}$ and the annual mean air temperature was $7{ }^{\circ} \mathrm{C}$ based on the records from 1981 to 1990. One of the most characteristic feature of the weather in this area is that the land is covered with snow from December to early April.

\section{METHODS}

The soil moisture was monitored during from 1992 to 1994 . Heat probes were embedded horizontally at the depths of $0.1,0.25,0.5$ and $0.75 \mathrm{~m}$ in the forest and the grassland, and at the depths of $0.1,0.25,0.5$ and $0.75 \mathrm{~m}$ in 1992 and 0.1 and $0.3 \mathrm{~m}$ in 1993 and 1994 in the wheat field.

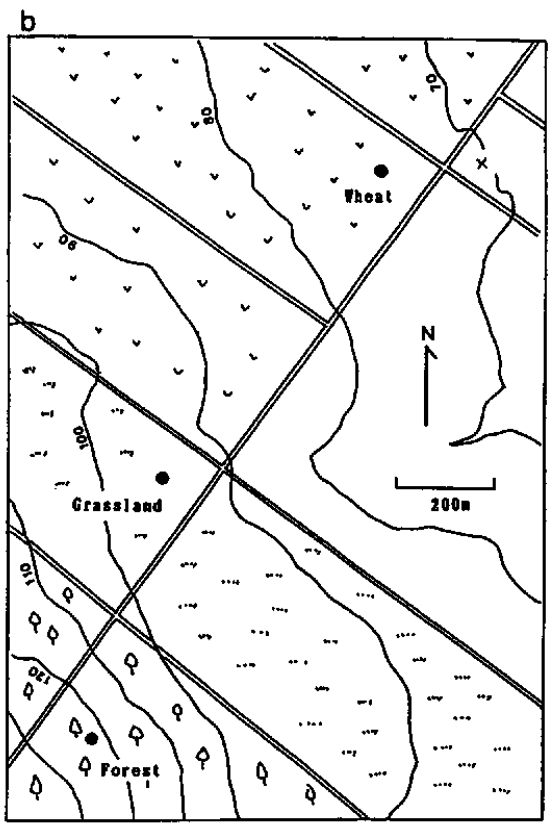

$x$ Weteorological station

Fig. 1 a: Illustration of Hokkaido district in Japan. b: The layout of forest, grassland, wheat field and meteorological station. Numbers in the figure show the heights above the sea level. 
Table. 1 Vegetation-type, soil classification, texture and solid ratio.

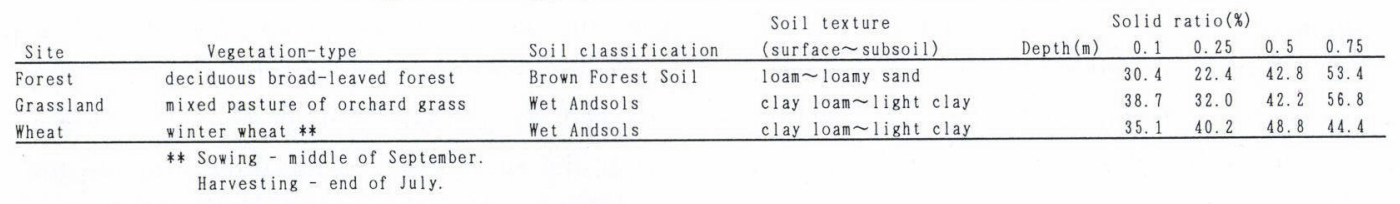
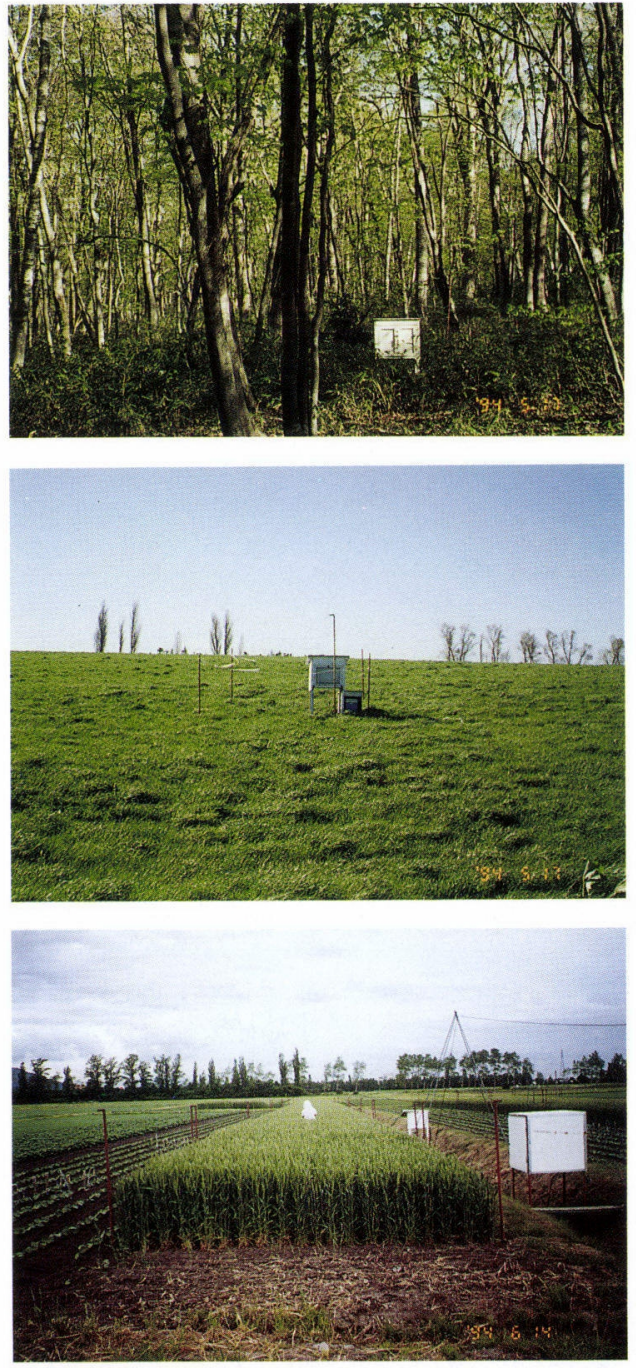

Fig. 2 Scene of forest, grassland and wheat field.

The heat probes also measured the soil temperature. The soil thermal conductivities and the soil temperatures were measured automatically in every hour. The soil thermal conductivities were converted into the volumetric water content using calibration curves for each

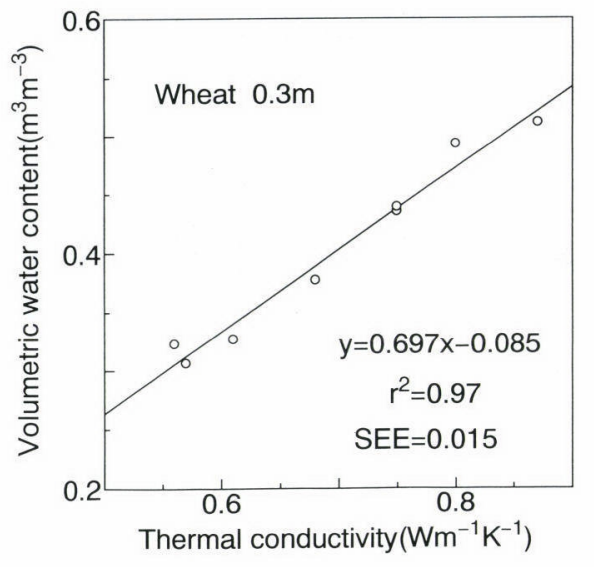

Fig. 3 The relationship between the soil thermal conductivity and the volumetric soil water content.

soil layer. Soil samples were taken from each soil layer at several times in a year for the calibration. The instrument was controlled by the computer (GreenKit 88, ESD Inc. and IDL-1600, NORTH-HIGHTECH Inc.). The relationship between the soil thermal conductivity and the volumetric soil water content in the wheat field is shown in Fig. 3. In this area, the soils are rarely frozen in winter by the deep snow cover though the air temperature is lower than $0{ }^{\circ} \mathrm{C}$. Thus, the calibration curves for each soil layer could be used even under the snow cover in winter.

\section{IV . RESULT AND DISCUSSION}

\section{Seasonal Variations in Soil Moisture}

Seasonal variations of precipitation and soil moisture for the forest, grassland and wheat field are shown in Fig. 4 (1992), Fig. 5 (1993) and Fig. 6 (1994). The snow depth in each vegetation in 1994 are shown in Fig. 7. The soil temperature under each vegetation in 1994 are shown in Fig. 8. 
The characteristics in seasonal variations of soil moisture were as follows. After the thaw the soil moisture tended to decrease to summer. Especially, in June and July the soil moisture was the driest because of the less rainfall and the high demand of evapotranspiration. In autumn, September and October, the soil mois-
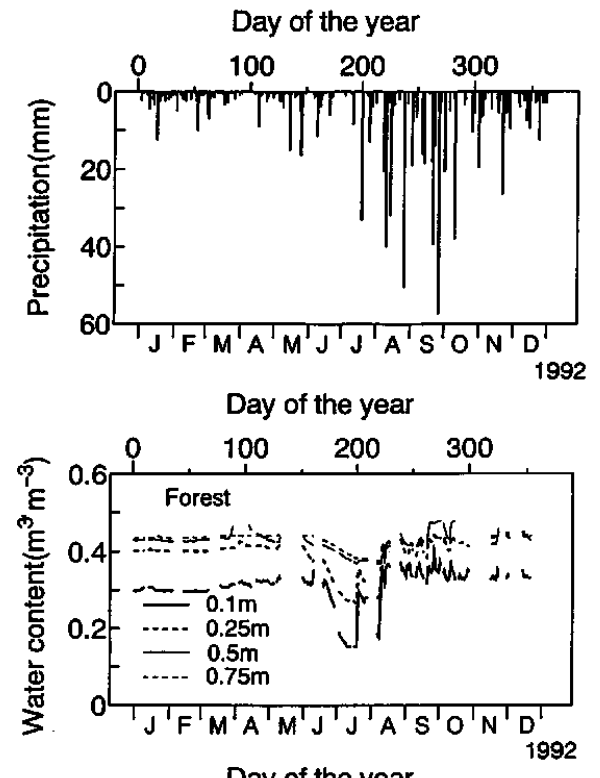

Day of the year

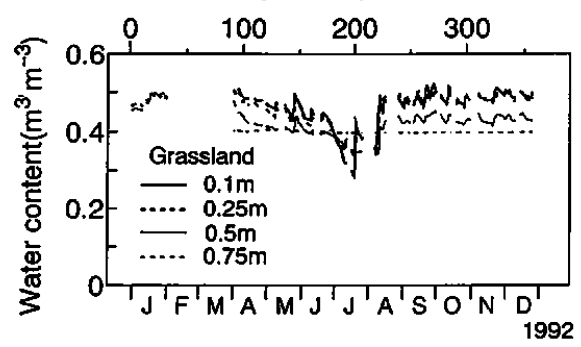

Day of the year

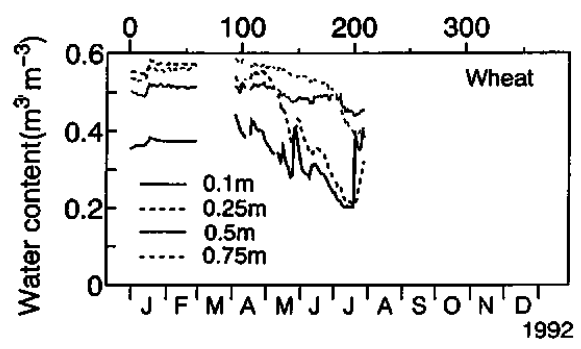

Fig. 4 Temporal variation of precipitation and soil moisture in forest, grassland and wheat field during 1992 (All data are daily value.). ture increased abruptly by the heavy rain. After that the wet condition of soil lasted until winter. In winter, the maximum snow depth reached more than $1 \mathrm{~m}$ as shown in Fig. 7 . After the snow covered the land, the soil moisture kept wet and constant until the thaw. In this period air temperature was almost lower
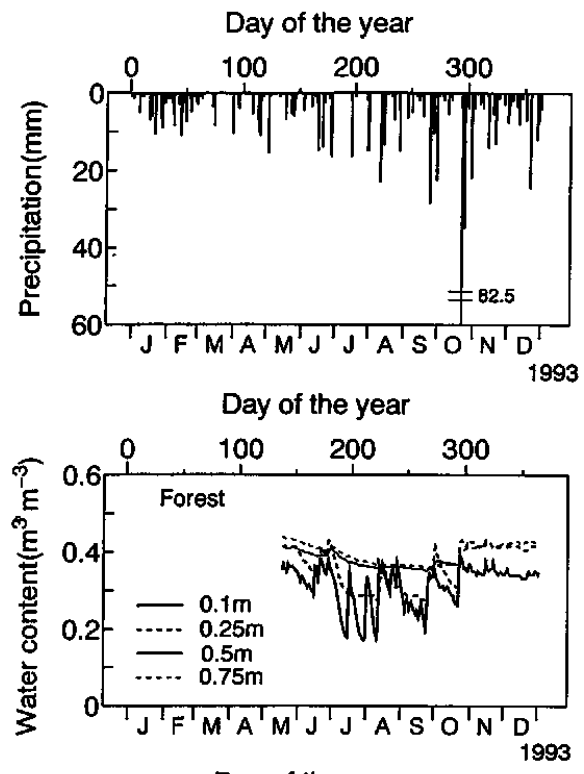

Day of the year

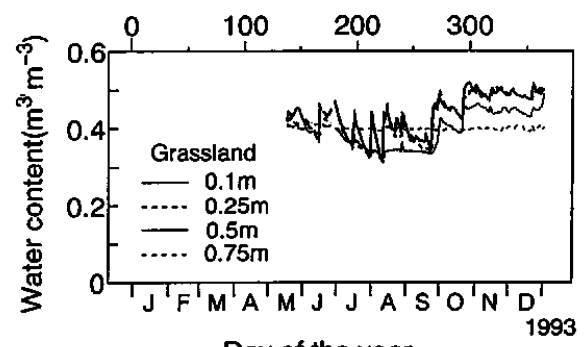

Day of the year

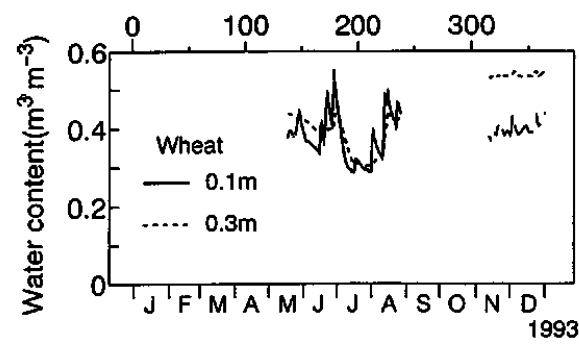

Fig. 5 Temporal variation of precipitation and soil moisture in forest. grassland and wheat field during 1993 (All data are daily value.). 
than $0^{\circ} \mathrm{C}$ but the soil temperature was higher than $0^{\circ} \mathrm{C}$ as shown in Fig. 8 and the soil was not frozen by the deep snow with which the soil was insulated thermally. The soil moisture reached maximum at the time of thawing in early April.
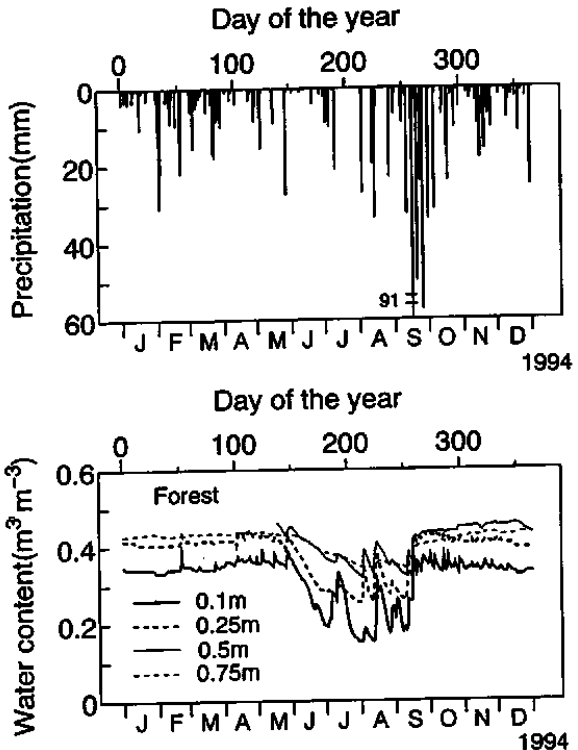

Day of the year

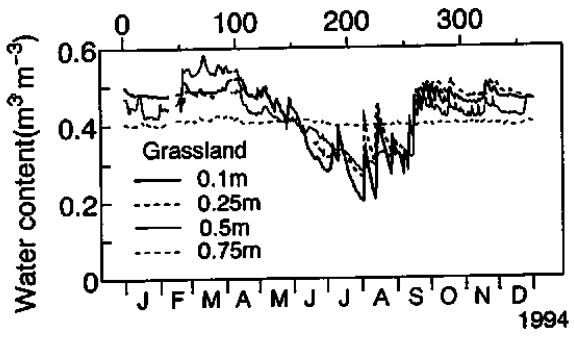

Day of the year

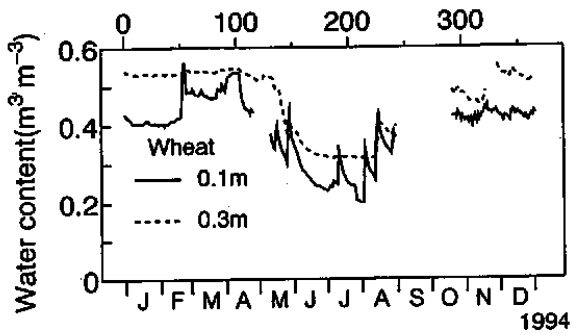

Fig. 6 Temporal variation of precipitation and soil moisture in forest. grassland and wheat field during 1994 (All data are daily value.).

\section{Effects of Vegetations on Soil Moisture}

The date of disappearance of the snow cover in the forest was delayed about ten days compared with other vegetations. Moreover, the succeeding decrease of the soil moisture in the forest was later than that in each of other vegetations. In the grassland and the wheat field, the soil moisture began to decrease soon after the thaw while in the forest the soil moisture tended to decrease around the end of May. These differences were caused in the initial time of activation of each vegetation. The grassland and the wheat field started to grow soon after the thaw while the forest which was consisted of the deciduous trees began to sprout at the middle of May.

From the thawing time to early summer, in the forest the soil moisture decreased simultaneously down to $1 \mathrm{~m}$ depth but, in the grassland, the soil moisture decreased simultaneously within $0.5 \mathrm{~m}$ depth. On the other hand, in the wheat field, the soil moisture decreased from a shallow to deeper horizon in order. These differences could be explained by the dependence on the root depth and the root structure. That is, in the forest, the roots of the trees are

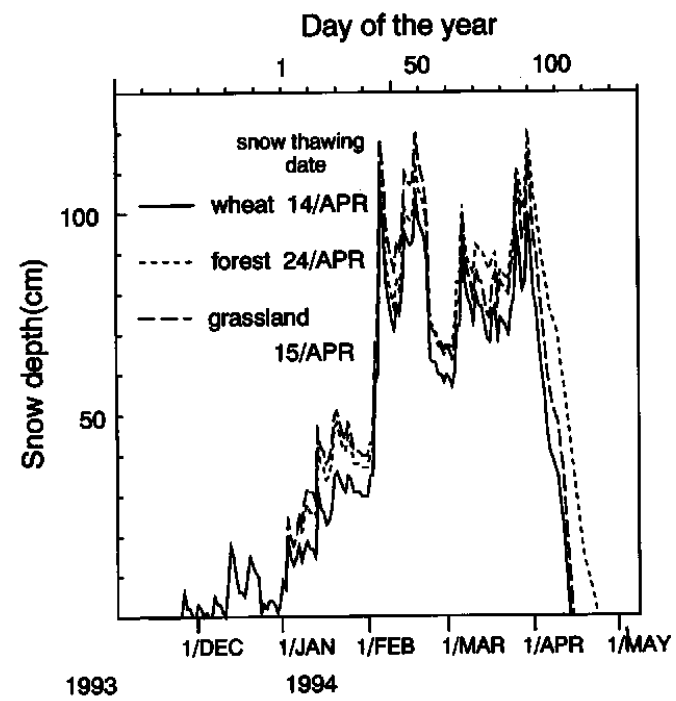

Fig. 7 Temporal variation of snow depth in forest, grassland and wheat field measured daily at 0900 hours during the 1994 . 


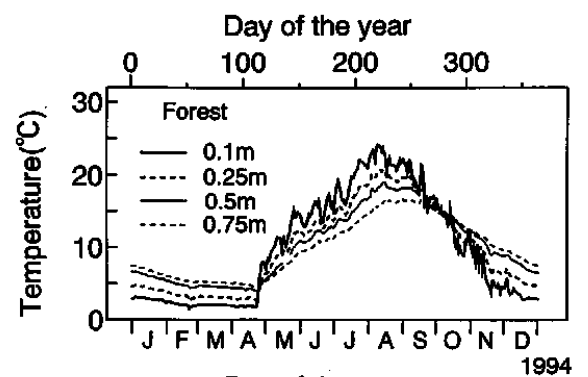

Day of the year
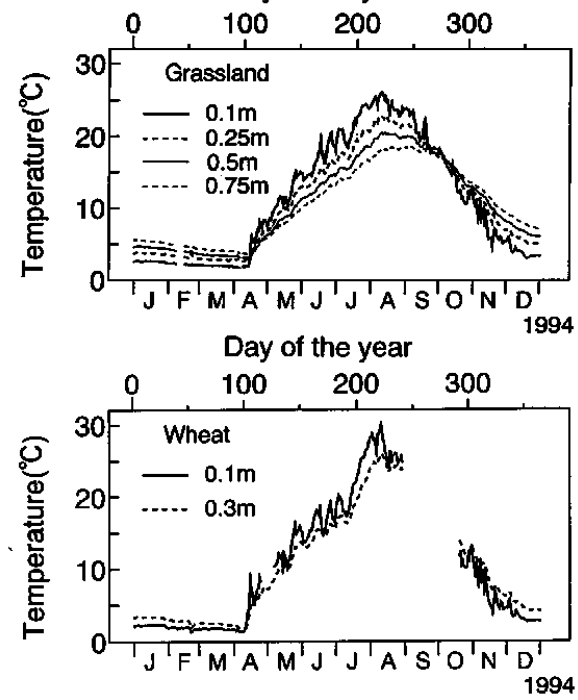

Fig. 8 Temporal variation of daily mean soil temperature, in forest, grassland and wheat field during the 1994 .

much deeper than other vegetations, while that of the grassland are concentrated around the surface soil and that of the wheat grew down. wards after the thaw.

The soil moisture in the forest was always lower than those other two fields. In the wheat field the soil moisture remarkably decreased at the depth of 0.1 to $0.3 \mathrm{~m}$ by the rapid growth of wheat and the water could not reach to $0.3 \mathrm{~m}$ depth even in the case of $20 \mathrm{~mm}$ precipitation in July as shown in Fig. 6 (1994). After the wheat was harvested in August, the field changed to a bare soil condition and the soil moisture including at $0.3 \mathrm{~m}$ depth increased with the precipitation. Thus, the soil moisture was influenced not only by the meteorological condition but also by the vegetation and human activities.
The soil moisture of the forest did not increase much in the thawing time compared with other vegetations. This is considered due to that the amount of melted snow in a day is smaller than other sites (10 days delayed) and also due to the well-structured soil by the tree roots which facilitate the infiltration of the melted snow to the deeper horizon.

\section{Soil Temperature}

Since snow remained longer in the forest than in the other vegetation fields and the leaves shaded the soil surface, the soil temperature in the forest was lower than in the other vegetation fields from spring to autumn. But in winter, the soil temperature in the forest was rather higher than in the other vegetation fields.

The soil temperature in the wheat field was lower than in the grassland in summer because the plant cover in the former is thicker than in the latter in this period. However, after the harvest of wheat, the soil temperature in the wheat field became higher than in the grassland.

\section{Differences of Soil Moisture among the Years}

As shown in Fig. 9, in the observation period (1992-1994), the meteorological conditions in summer were much different, that is, the air temperature was almost the same in 1992 as the averaged data from 1981 to 1990 , lower in 1993 and higher in 1994 than the average. These meteorological conditions affected the vegetation growth and eventually the soil moisture. The minimum values of soil moisture of each year in the grassland and the wheat field coincided with the meteorological fluctuations. That is, the soil moisture was the lowest in 1994, the highest in 1993 and intermediate in 1992. However the minimum values of soil moisture of each year in these three years were almost the same in the forest. This shows that effects of meteorological fluctuations on the plant activity were small in the forest compared with the other vegetations. 

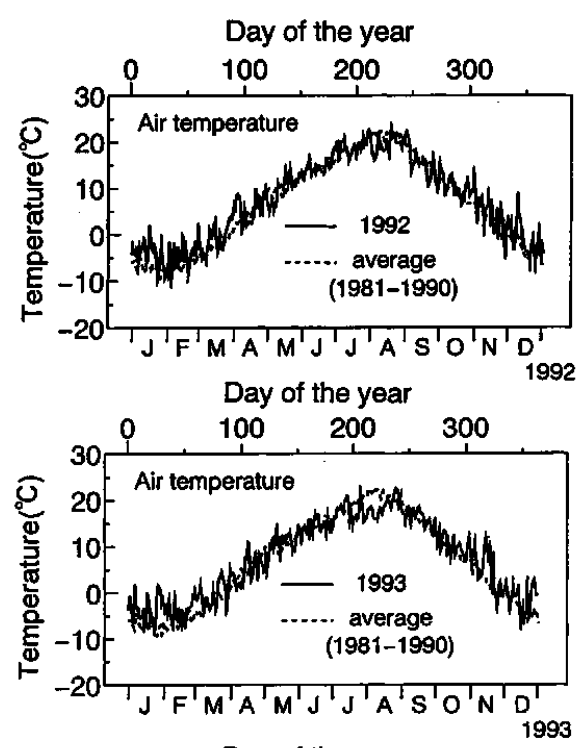

Day of the year

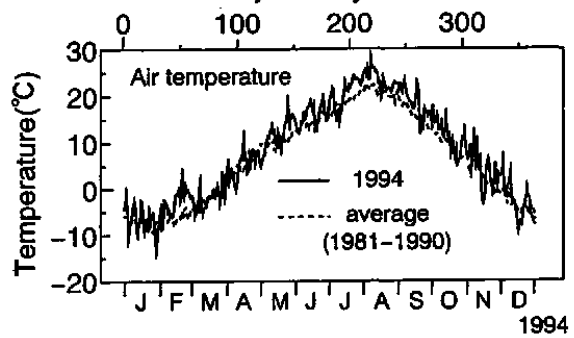

Fig. 9 Temporal variation of daily mean air temperature during from 1992 to 1994 .

\section{CONCLUSIONS}

We measured soil moisture under the different vegetations in a boreal humid climate for three years (1992-1994). Seasonal variations of the soil moisture was characterized into three stages; thawing to active vegetation (spring to summer), rainy (autumn) and snow covered (winter) period. The soil moisture and temperature were much influenced in the active time and the root system of each vegetation. Differences in soil moisture among the years depended on the meteorological conditions which affected the vegetation growth. Through the observations, it was revealed that the soil mois. ture and temperature were influenced mainly by the meteorological conditions but also by the vegetations.
The heat and mass transfer between the atmosphere and the land surface influences the physical condition of both the atmosphere and the soil. In order to analyze the land-atmospheric interactions in the field, it is inevitable to measure the soil physical conditions; especially the soil moisture and soil temperature with the atmospheric conditions.

ACKNOWLEDGEMENTS : The authors would like to thank to Mr.Syuji Yanagiya, Mr.Koji Yoshida and Mr. Yoshihiro Ohta of Hokkaido National Agricultural Experiment Station for their assistance of the observations. The authors also would like thank to Dr.Tsuyomi Mizuochi and Dr. Tsuneo Nitta of Hokkaido National Agricultural Experiment Station for their cooperating in the wheat field.

\section{REFERENCES}

1) Hasegawa, S. and Kasubuchi, T., (1993): Water regimes in fields with vegetation. In: Tsuyoshi Miyazaki (Editors), Water flow in soils, Marcel Dekker, New York, pp.244253.

2) Hollinger, S. E. and Israd, S.A., (1994): A soil moisture climatology of Illinois, $\mathrm{J}$. Climate, 7: pp. 822-833.

3) Kasubuchi, T., (1977): Twin transientstate cylindrical-probe method for the determination of the thermal conductivity of soil, Soil Sci. 124: pp.255-258.

4) Kasubuchi, T., (1982): Heat conduction of soil, (in Japanese with English summary), Bull. Natl. Inst. Agric. Sci. Ser. B33: pp. $1-54$.

5) Kasubuchi, T., (1992): Development of insitu soil water measurement by heat-probe method, Jpn. Agric. Res. Q. 26: pp. 178181.

6) Vinnikov, K. YA., and Yeserkepova, I. B., (1991): Soil moisture: empirical data and model results, J. Climate, 4: pp.6679 .

（1995年11月15日受付，1996年 1月18日受理） 